\title{
Peer Feedback in Computer Aided College English Writing Instruction
}

\author{
Zhuo Ma \\ Foreign Languages and Cultures Department, 10049 Beijing Wuzi University, China
}

\begin{abstract}
This study is to examine the acceptability of peer feedback in computer aided college English writing instruction. For the whole writing procedure, subjects in language labs were to take preparation, writing and evaluation stages, undergoing three editions suggested by peer feedbacks. For the first time reading, peers would comment on such general scale as subject and content of drafts, and the second focuses on specific items, for example the morphological, lexical and syntactical aspects, etc. To compare students' attitudes towards the trial, before and after the experiment, Pre-Questionnaire and Post-Questionnaire were adopted to analyze differences. From the frequency of students' views on ten statements, it is drawn that majority of subjects accept and enjoy the innovative writing process, since peer feedback is an essential and encouraging part for writing.
\end{abstract}

\section{Introduction}

With the development of computer technology in scientific era, computer-based teaching methodology is popularly advocated. Students under computer and net environment, can process information online, learn to construct, and communicate smoothly with peers and teachers. Network puts an inspiring set of tools within reach of the mass of computer users. According to College English Curriculum Requirements (2007), the new teaching reform should emphasize on computer applications, which may provide an updated solution to traditionally ineffective teaching techniques, soothing students' writing anxiety in classrooms, and boosting their confidence and motivation in learning.

Writing has been the weakest aspect in college English teaching, since teachers spend considerable time and energy to improve students' writing ability, yet the effects prove less fruitful. Basically speaking, this unpromising condition is to great extent attributed to the prevailing Product Writing Approach. This teaching mode is to have students write and teachers respond individually and separately, with teachers' written comments as the only feedback. Teachers' correction is the terminal and judgment of whole process of composing, therefore the majority of students either neglect comments or care little about grades, instead of perfecting.

With appearance of computer-assisted foreign language learning mode, writing instructions have been converted, from focus on result to process, from teachers' single reading and correcting to such collaborative learning activities by students as group discussion, presenting suggestions and feedbacks, cooperatively editing compositions, etc. Feedback in teaching writing

\footnotetext{
${ }^{\mathrm{a}}$ Corresponding author: mazhuo@bwu.edu.cn
}

refers to "the inputs to writers by readers, aiming at providing editing information for writers" [1]. Yet for feedback from teachers and peers, the latter outdo the former, as "peer feedback conform to the cognitive principle that concepts are internalized into individual knowledge through social communication" [2]. Contacts by peers with same cognitive level is more helpful in stimulating cognitive development than those from others. Reading others' papers may raise one's own sense of readers, who tend to recognize more clearly problems in their own compositions, by way of reading others, giving and accepting others' feedbacks. Besides, group discussions push students to learn from each other, and mutual correction build up their sense of responsibility so as to rely less upon teachers [3].

\section{Peer feedback in NHCE based writing mode}

NHCE (New Horizon College English) Online Learning System is devised as companion to NHCE Textbooks and advantageous for computer-aided writing instruction, which is presented as the follows.

\subsection{Preparation stage}

After the first unit in NHCE is learned, teachers release writing requirements on Class Notice in Teaching Interaction on the page of NHCE learning system. Once students $\log$ onto the NHCE system and notice the assignment, the distribution of workload within one group is carried out. Students bearing different duties begin to surf online, gathering whatever they need for this writing assignment, including writing samples, relevant grammars and reading passages, or any necessary 
materials in video, audio and text forms. Then each donator sends their findings to the teacher by campus email, which being assorted and classified, are uploaded by the teacher on Teaching Handouts in NHCE system for students to read and internalize. Being brainstormed, students are stimulated and turn to communicate with teacher and partners. Online group discussing and questioning through Interactive Tool on NHCE ensue for writers to compare, delete and borrow ideas, and finally their own outline is generated.

\subsection{Writing stage}

Once definite thoughts are set, each student type their thinking flow onto Teacher-Student Discussion in Online Class part in NHCE system for both the teacher and students to read, evaluate and learn. Realizing that their product would be examined by audience, writers may purposefully avoid making mistakes, rack brains to improve and better the quality of drafts. When every essay appears online, mutual evaluation follows. Students edit others' passages, underline improper lines and paragraphs, and write down comments as well as suggestions below the version. Since it is the first draft evaluation, the teacher need to set rules of focusing reading perspective on aspects of subject and content. For example, students are supposed to answer the following questions while evaluating others' first draft.

- What is the best and strongest point of the article?

- Where does the shortcoming lie?

- What subject and idea does this essay convey?

- Which points of view need further explaining and stating?

- Which parts of the draft are to be added with more examples and details?

- What questions are unanswered?

- On what aspects cannot the draft attract readers and why?

- Which part of the article is loosely structured and disordered?

- Which parts are confusing and ambiguous in points?

Taking all suggestions into consideration, each subject accordingly begins to rewrite and revise the first draft, which no doubt can prove a better version. When the version is submitted online, the second round of peer reading follows. During this makeup period, the teacher specially notify editors of certain rules, such as language accuracy of grammar, spelling, expressions, and punctuations in morphological, lexical and syntactical aspects, in contrast to concentration on content in the first draft revision. The followings are some tips to refer.

- Is the Verbal Tense used properly?

- Is the verbal form accurate?

- Does the predicate agree with the subject?

- Are the prepositions used precisely?

- Are the necessary articles lost?

- Is the pronoun definitely referred? Do person and number agree?

- Are adjectives and adverbs properly used?

- Is the sentence structure complete?

\subsection{Evaluation stage}

As the final draft is composed, students once more come to read others' new editions, judge and vote for Excellency. Likewise, 4-5 best papers and 9-10 better ones are chosen and kept by the teacher on Sample Writings Column on NHCE system. The teacher's generalization marks the final step. The whole-scale summary covers students' mastery of syntax, discourse, subject, the quality of peers' feedbacks, etc. Meanwhile, students' performances in whole stages are commentated and graded, namely the extent of fulfilling duties, the degree of donation in communications, and how serious the attitude in peers' feedback, etc.

\section{Questionnaires and discussions}

In order to examine students' attitudes and adaptation towards the new teaching method and peer feedback, 120 students of four classes in Beijing Wuzi University were selected as subjects. Before the experiment was carried out, they took a Pre-Questionnaire. When one-term writing practice drew to end, the other Post-Questionnaire was filled. It is believed that with those voting for or disagreeing with similar statements in two questionnaires, effects of peer feedback could be generally shown.

Table 1. Frequencies of students' views on feedback in NHCE based writing mode in Pre-Questionnaire and PostQuestionnaire

\begin{tabular}{|c|c|c|c|c|c|c|c|}
\hline \multirow{2}{*}{\multicolumn{2}{|c|}{ Statements }} & \multicolumn{2}{|c|}{ SA\&A } & \multicolumn{2}{|c|}{ Neutral } & \multicolumn{2}{|c|}{ SD\&D } \\
\hline & & $\mathrm{N}$ & $\%$ & $\mathrm{~N}$ & $\%$ & $\mathrm{~N}$ & $\%$ \\
\hline \multirow{2}{*}{$\begin{array}{c}\text { 1. I like to } \\
\text { have English } \\
\text { writing class }\end{array}$} & $\begin{array}{c}\text { Pre- } \\
\text { Q }\end{array}$ & 27 & 23 & 37 & 31 & 57 & 48 \\
\hline & $\begin{array}{c}\text { Post- } \\
\text { Q }\end{array}$ & 75 & 63 & 19 & 16 & 26 & 22 \\
\hline \multirow{2}{*}{$\begin{array}{l}\text { 2. While } \\
\text { writing, I } \\
\text { realize there } \\
\text { will be } \\
\text { readers for my } \\
\text { paper. }\end{array}$} & $\begin{array}{c}\text { Pre- } \\
\text { Q }\end{array}$ & 5 & 4 & 14 & 12 & 101 & 84 \\
\hline & $\begin{array}{c}\text { Post- } \\
\text { Q }\end{array}$ & 84 & 70 & 23 & 19 & 13 & 11 \\
\hline \multirow{2}{*}{$\begin{array}{l}\text { 3. I would } \\
\text { rather write } \\
\text { independently } \\
\text { than work } \\
\text { with peers. }\end{array}$} & $\begin{array}{c}\text { Pre- } \\
\text { Q }\end{array}$ & 83 & 69 & 18 & 15 & 19 & 16 \\
\hline & $\begin{array}{c}\text { Post- } \\
\text { Q }\end{array}$ & 11 & 9 & 14 & 12 & 95 & 79 \\
\hline \multirow{2}{*}{$\begin{array}{l}\text { 4. I would } \\
\text { accept } \\
\text { teachers' } \\
\text { feedback } \\
\text { instead of } \\
\text { peers. }\end{array}$} & $\begin{array}{c}\text { Pre- } \\
\text { Q }\end{array}$ & 77 & 64 & 21 & 18 & 22 & 18 \\
\hline & $\begin{array}{c}\text { Post- } \\
\text { Q }\end{array}$ & 21 & 18 & 31 & 25 & 68 & 57 \\
\hline \multirow{2}{*}{$\begin{array}{l}\text { 5. I like to } \\
\text { have peers } \\
\text { read and } \\
\text { evaluate my } \\
\text { compositions. }\end{array}$} & $\begin{array}{c}\text { Pre- } \\
\text { Q }\end{array}$ & 11 & 9 & 26 & 22 & 83 & 69 \\
\hline & $\begin{array}{c}\text { Post- } \\
\text { Q }\end{array}$ & 79 & 66 & 24 & 20 & 17 & 14 \\
\hline
\end{tabular}




\begin{tabular}{|c|c|c|c|c|c|c|c|}
\hline \multirow{2}{*}{$\begin{array}{l}\text { 6. Writing is a } \\
\text { difficulty task } \\
\text { to fulfill. }\end{array}$} & $\begin{array}{c}\text { Pre- } \\
\text { Q }\end{array}$ & 97 & 81 & 16 & 13 & 7 & 6 \\
\hline & $\begin{array}{c}\text { Post- } \\
\text { Q }\end{array}$ & 28 & 23 & 36 & 30 & 56 & 47 \\
\hline \multirow{2}{*}{$\begin{array}{l}\text { 7. Writing is } \\
\text { an important } \\
\text { competence. }\end{array}$} & $\begin{array}{c}\text { Pre- } \\
\text { Q }\end{array}$ & 104 & 87 & 12 & 10 & 4 & 3 \\
\hline & $\begin{array}{c}\text { Post- } \\
\text { Q }\end{array}$ & 108 & 90 & 9 & 8 & 3 & 3 \\
\hline \multirow{2}{*}{$\begin{array}{l}\text { 8. I read and } \\
\text { correct my } \\
\text { paper before it } \\
\text { is submitted. }\end{array}$} & $\begin{array}{c}\text { Pre- } \\
\text { Q }\end{array}$ & 26 & 22 & 37 & 31 & 57 & 48 \\
\hline & $\begin{array}{c}\text { Post- } \\
\text { Q }\end{array}$ & 83 & 69 & 17 & 14 & 20 & 17 \\
\hline \multirow{2}{*}{$\begin{array}{l}\text { 9. I rewrite } \\
\text { the paper with } \\
\text { teachers' } \\
\text { comments. }\end{array}$} & $\begin{array}{c}\text { Pre- } \\
\text { Q }\end{array}$ & 13 & 11 & 23 & 19 & 84 & 70 \\
\hline & $\begin{array}{c}\text { Post- } \\
\text { Q }\end{array}$ & 92 & 77 & 17 & 14 & 11 & 9 \\
\hline \multirow{2}{*}{$\begin{array}{l}\text { 10. I would } \\
\text { rather write } \\
\text { another paper } \\
\text { than rewrite } \\
\text { and edit. }\end{array}$} & $\begin{array}{c}\text { Pre- } \\
\text { Q }\end{array}$ & 102 & 85 & 13 & 11 & 5 & 4 \\
\hline & $\begin{array}{c}\text { Post- } \\
\text { Q }\end{array}$ & 24 & 20 & 35 & 29 & 61 & 51 \\
\hline
\end{tabular}

Note: $\mathrm{N}=120$, Pre-Q=Pre-Questionnaire, Post-Q=Post-

Questionnaire, $\mathrm{SA}=$ Strongly Agree, $\mathrm{A}=$ Agree, $\mathrm{N}=$ Neutral, $\mathrm{SD}=$ Strongly Disagree, $\mathrm{D}=$ Disagree

From the frequencies of Students' Views on Feedback in NHCE Based Writing Mode in Pre-Questionnaire and Post-Questionnaire, the comparisons of ten items are listed. Before the research, nearly half (48\%) of subjects did not like writing classes, with $31 \%$ students holding indifferent views, while after the training, 63\% students began to favor the new writing course. Specifically speaking, for Pre-Questionnaire, only 4\% subjects realized the existence of readers while writing, while $84 \%$ of them bore no sense of readers. However, after the study, 70\% students raised the consciousness of readers, which enhanced their sense of writers. For collaborative study, 69\% students refused to work with partners on writing beforehand, while experiencing group discussions and distributions of duties, only $9 \%$ students stuck to this attitude, and the frequency of those willing to accept collaborative work rose from $16 \%$ to $79 \%$. As for feedback, most of students (64\%) initially took teacher as authority and their evaluation convincing, yet once peer feedback was employed in computer based writing instruction, 57\% students no longer regarded teacher as absolute authority. Accordingly, only 9\% students had some idea about peer evaluation at outset of the trial; instead, afterwards $66 \%$ of them showed interest and preference for peers' comments. When asked whether writing is difficulty or not, of students instructed by traditional teaching mode, $81 \%$ of them reported their sufferance, while undergoing the innovative instruction, the number drops to $23 \%$. However, no matter when questioned about significance of writing ability, overwhelmingly students vote for its importance. As writing is conducted by Product oriented approach, nearly half students $(48 \%)$ never edit original versions, but for Post-Questionnaire, the frequency of those tending to rewrite rise to $69 \%$. Previously, $11 \%$ students would like to reshape their papers by following teachers' comments, and $70 \%$ would not even take a look, $85 \%$ students would rather compose another than rewrite, however as the new strategy was put to end, $77 \%$ subjects began to realize the value of feedback, tend to work for better version, and half of them $(51 \%)$ got rid of former attitude.

So far from the statistics presented above, it is drawn that peer feedback in NHCE writing instruction is beneficial to English learners in the following aspects. First, since students will reconsider and edit their own language output while sending out feedback to others, to guarantee accuracy of information, they are more likely to center on language itself, thus their writing skill and competence can be enhanced. Secondly, under the online environment where messages are frequently exchanged, teachers can perform their role of monitors by keeping students' communications under control so as to guide timely and specifically. Lastly, students connected online may find themselves more relaxed and less nervous in discussing, evaluating, giving suggestion and feedback, which helps to ease worries and tension. Therefore, this computer based writing approach prove more attractive, in which students are more willing to speak out one's own ideas and comments including criticisms, and either part tends to share the other's true opinions. Consequently, peer feedback is effective in editing papers and improving writing competence.

\section{Conclusion}

In China, most of college teachers are still employing traditional techniques, with little achievements and accomplishments. Teachers bear heavy workload and could hardly instruct students individually. Basically the sense of application of computer technology to English teaching hasn't been aroused. Or teachers may have borrowed and tried certain Computer Aided Writing Instruction strategies as QQ, Email, or Blog into writing class, however, instructors have touched rather limited tools and functions in their textbooks related learning systems, which under campus environment, is more convenient and economical. To utilize school based online learning system to teach in writing course, and emphasize peer feedback as evaluation in the midst of writing, is where this study suggests. With peer feedback proving effective and acceptable, the new approach in writing instruction is highly advocated so as to fully benefit both learners and teachers.

\section{References}

1. L. KEHC. Feedback in the writing process: A model and methods for implication. ELT Journal. 44(1990).

2. Y. Xianhai, et W. Yuehui. The Application of Collaborative Learning Principle in English Teaching. Foreign Language Education. 5(2003). 
3. G. Cuihong et Q. Xiaoqing. The study on written feedback of compositions by foreign second language learners - - The perspective of study and its implication on college English writing evaluation. Journal of PLA University of Foreign Languages. 9(2006). 